\title{
TEACHERS' ATTITUDES AND OPINIONS ON MATHEMATICS LESSONS CONDUCTED WITH DISTANCE EDUCATION DUE TO COVID-19 PANDEMIC
}

\author{
Baris DEMIR \\ ORCID: 0000-0001-6997-6413 \\ Hereke Omer Ismet Uzunyol Vocational School \\ Kocaeli University \\ Kocaeli, TURKEY \\ Dr. Gul KALELI YILMAZ \\ ORCID: 0000-0002-8567-3639 \\ Education Faculty \\ Bursa Uludag University \\ Bursa, TURKEY \\ Hulya SERT CELIK \\ ORCID: 0000-0002-5021-7449 \\ Icmeler I.C.K.K.A Secondary School \\ Mugla, TURKEY
}

Received: 28/08/2020 Accepted: 02/03/2021

\begin{abstract}
Distance education has become widespread since the schools are physically closed due to COVID-19 pandemic. This study concentrates on determining attitudes of teachers towards distance mathematics education and examining their views based on some variables. Participants of the study consists of 189 teachers who voluntarily participated to the study, are selected via maximum variation sampling method, are working in primary, secondary and high school levels in provinces of Mugla and Kocaeli, and who teach Mathematics via distance education platforms. This study relies on mixed-method research where data collection was done with distance education attitude scale and view form, both prepared and applied online. Data from distance education attitude scale was analyzed quantitatively and data from view form was analyzed with descriptive analysis method. The result of the study demonstrated that attitudes of teachers towards distance mathematics education were indecisive but in negative direction. While attitudes of teachers towards distance mathematics education were found to differ significantly based on some variables like age, occupational experience, type of school, level of education and foreknowledge towards distance education, they did not differ significantly for gender and duration of internet use. Moreover, teacher also remarked positively towards sustainability and repetitive nature of the courses while they commented negatively on technical problems and structure of some courses may not fit in distance education.
\end{abstract}

Keywords: COVID-19, mathematics, attitude, distance education.

\section{INTRODUCTION}

Due to COVID-19 pandemic where the world is facing a big crisis, life has almost stopped except from some basic services. Education is one of the most important of all. Almost \%90 of students across the world has been deeply affected by this situation (UNESCO, 2020). 
Although schools were physically closed in many countries including Turkey for making health of students and all humanity safe during COVID-19 pandemic, various practices have been made to make learning sustainable in our country. The core of these practices mainly consists of distance learning. As known, distance learning is an education model where students and teachers carry out teaching and learning relations in different times and places with communication technologies and e-mails (Isman, 2005). Distance education has different forms in education systems. Along with beginning of internet use in distance education, the concepts of e-learning, internet based education, mobile learning, web-based education have been started to use (Yildiz, 2011). Distance education might be carried out in three ways depending on the need; asynchronous, synchronous and mixed. Asynchronous learning environments are flexible environments where course content is prepared beforehand, participants can communicate through online environments like e-boards, e-mail or forum and they can access to the content as many times as they want even if they are not in the same system (Hrastinski, 2008). Synchronous learning environments, on the other hand, are real time learning environments where students and teachers can communicate aurally or written even if they are in different physical places (Patton,2008). Mixed model includes both modals together in the same modal.

When causes which makes distance education compulsory are examined, a number of factors like equality in opportunity, decrease in cost, providing education to individuals regardless of age and based on their needs, accessing more learners than conventional education does, making communication between individuals and maintaining cultural unity (Cetin, 2010). But, these days showed us that we should also count causes pandemics.

Having worked so hard during this pandemic to make education sustainable, Turkey ensures distance education in primary and secondary schools in two basic ways: (i) (EBA) Educational Information Network which was already founded before with a well-established infrastructure as well as recently updated rich contents, (ii) TV channels (TRT-EBATV) which broadcast video courses according to different grade levels. Moreover, teachers also contribute this process by communicating with their students via teleconference courses and questions, as well as sharing resources through the system and even following students' assignment from the system. Distance education in our country during the pandemic is being carried out with mixed modal approach.

There have been many researches on distance education so far in the literature. For instance, when attitudes of teachers towards distance education is considered; there have been many studies which indicates positive attitudes (Agir, Gur and Okcu, 2008; Celen, Celik and Seferoglu, 2013; Yilmaz and Guven, 2015; Yenilmez, Balbag and Turgut, 2017), indecisive attitudes (Ates and Altun, 2008) and negative attitudes (Yilmaz and Guven, 2015). Apart from attitudes, there have also been some studies on the effect of distance education on success. While some of them claims that distance education in mathematicss affect success more than conventional education (Hwang, Vu, and Chen; 2012; Lin, 2009; Ozyurt, 2012; Tsuei, 2012; Yorganci, 2013), there have also been some others which put forward that conventional education is more effective than distance education (Li, Uvah, Amin and Hemasinha, 2009; Paden, 2006). Besides, Javed (2008) argues that there is no difference between distance and conventional education. When the studies conducted in recent years are examined, it is seen that the studies comparing distance education and traditional education have decreased (Aktas, 2013). Comparison studies have been replaced by determining which types of distance education activities are effective in increasing success, and what perceptions and opinions of students are about distance education. Studies conducted in distance education activities include visual, sound and communication problems, limited interaction, body language used by teachers and time allocated for lessons, etc. It reveals that factors affect participants' perceptions of distance education (Koppelman \& Vranken, 2008; Marsh, Mitchell \& Adamczyk, 2010). In addition, it is observed that concurrent distance education activities are insufficient to meet the expectations of the participants for education (Delaney, Jacob, Iedema, Winters \& Barton, 2004). In addition, it has been stated that verbal lessons can be taught effectively with distance education, but some technical lessons that require practice cannot be given in a healthy way with distance education, so it would be more beneficial to use distance education as a teaching method that supports traditional education (Horzum, 2003; Alakoc, 2001).

As seen above, there have been many studies on distance education but what matters here is that all studies so far have taken distance education as an alternative or a supplementary method. Yet, it has been seen during this pandemic that distance education is not an alternative, it has become compulsory. For this reason, every 
educator and learner with or without distance education experience had to teach or take lessons by distance education method due to the pandemic process. Educational institutions and educators operating in this field have sought how to conduct distance education courses and how to use online tools in this process (Karip, 2020). In this context, with regard to distance education, it can be stated that the world will no longer be the same (Durak, Cankaya, \& Izmirli, 2020). In this process, it is seen that most of the trainers have never used distance education tools before (Cetinkaya Aydin, 2020). Considering that these trainers have limited knowledge and skills in teaching distance education and preparing distance education material, it cannot be said that this process will continue completely. In case of any extension of pandemic and going on distance education in later periods, views of teachers have gained importance in determining what to do to make distance education practices better. With this in mind, this study aims at determining attitudes of teachers towards distance mathematicss education and examining their views based on some variables. In line with this aim, the following problems were posed: attitudes of teachers towards Mathematics lessons in distance education, gender, age, occupational experience, type of school, level of education, duration of internet use and foreknowledge on distance education. Accordingly, the following questions were addressed:

1. How attitudes do teachers have towards mathematics lessons in distance education?

2. How do teachers' attitudes change according to the variables of gender, age / professional experience, school where they work, education level, internet usage time and prior knowledge about distance education?

3. What are the views of teachers towards mathematics lessons in distance education?

\section{METHOD}

The mixed method provides a much better understanding of the research problem by using quantitative and qualitative approaches together (Cresswell \& Plano Clark, 2007). In this study, one of the Cresswell (2003) designs of the mixed method, "sequential explanatory design" was used. In this design, qualitative data are often collected after quantitative data are collected. The priority is on quantitative data, qualitative data are obtained to support quantitative data. The data are analyzed separately and combined in the interpretation and discussion section (Gokcek, 2019). While qualitative method of research, makes data analysis more detailed via observation, interview etc., the data collected with the quantitative method approach helps to reach more participants (Greene et al., 1989). In the study, quantitative data obtained from applying a scale to the study group was supported by qualitative data obtained from a semi-structured interview form with a group of participants.

\section{Participants}

Teachers who attend mathematics lessons and teach at least once distance education and mathematics lessons are determined as the universe of the study. Since it would not be possible to reach the entire universe and the sampling method of the mixed research method, the "appropriate sampling" method was preferred. In the appropriate sampling, a sample that is both easily accessible and willing to participate in the study is selected (Gokcek, 2019). The study group of the research consists of 189 volunteer teachers working in primary, secondary and high schools in Mugla and Kocaeli provinces determined by the maximum variation sampling method in 2019-2020 academic years, and teaching mathematics with distance education. The reason for choosing these two provinces is that researchers work in these provinces and have easier access to teachers working in these provinces. Demographic information of the teachers participating in the study is given in Table 1. 
Table 1. Demographic info of participant teachers

\begin{tabular}{|c|c|c|c|}
\hline Variable & Category & $f$ & $\%$ \\
\hline \multirow{2}{*}{ Gender } & Female & 138 & 73,0 \\
\hline & Male & 51 & 27,0 \\
\hline \multirow{4}{*}{ Age } & $20-30$ years & 48 & 25,4 \\
\hline & 31 - 40 years & 126 & 66,7 \\
\hline & $41-50$ years & 12 & 6,3 \\
\hline & $51-60$ years & 3 & 1,6 \\
\hline \multirow{5}{*}{ Experience } & $1-5$ years & 15 & 7,9 \\
\hline & $6-10$ years & 72 & 38,1 \\
\hline & $11-15$ years & 72 & 38,1 \\
\hline & $16-20$ years & 24 & 12,7 \\
\hline & 21 years and above & 6 & 3,2 \\
\hline \multirow{3}{*}{ School Type } & Primary & 55 & 26,6 \\
\hline & Secondary & 111 & 58,7 \\
\hline & High-School & 24 & 12,7 \\
\hline \multirow{2}{*}{ Education Level } & Undergraduate & 165 & 87,3 \\
\hline & Graduate & 24 & 12,7 \\
\hline \multirow{4}{*}{$\begin{array}{l}\text { Weekly Use of Inter- } \\
\text { net }\end{array}$} & 1- 2 days & 18 & 9,5 \\
\hline & 3- 4 days & 24 & 12,7 \\
\hline & $5-6$ days & 30 & 15,9 \\
\hline & Everyday & 117 & 61,9 \\
\hline \multirow{3}{*}{$\begin{array}{l}\text { Foreknowledge on } \\
\text { DE }\end{array}$} & Less knowledge on DE & 30 & 15,9 \\
\hline & Sufficient knowledge on DE & 130 & 65,1 \\
\hline & Already lectured in DE & 36 & 19,1 \\
\hline Total & & 189 & 100,0 \\
\hline
\end{tabular}

According to Table 1, the majority of teachers included in the study were female $(73 \%)$ and the age range was between $31-40$. Approximately $80 \%$ of the teachers participating in the research consist of teacher groups with 6 to 10 years and 11 to 15 years of professional experience. In terms of the school type of teachers; it is seen that the secondary school teachers are about $60 \%$ and the primary school teachers are $30 \%$. It was found that a significant number of teachers use the internet every day of a week and they have sufficient information about distance education. In addition, the technological tools they use and their purposes of using the internet are shown in Graph 1 and Graph 2 below. 


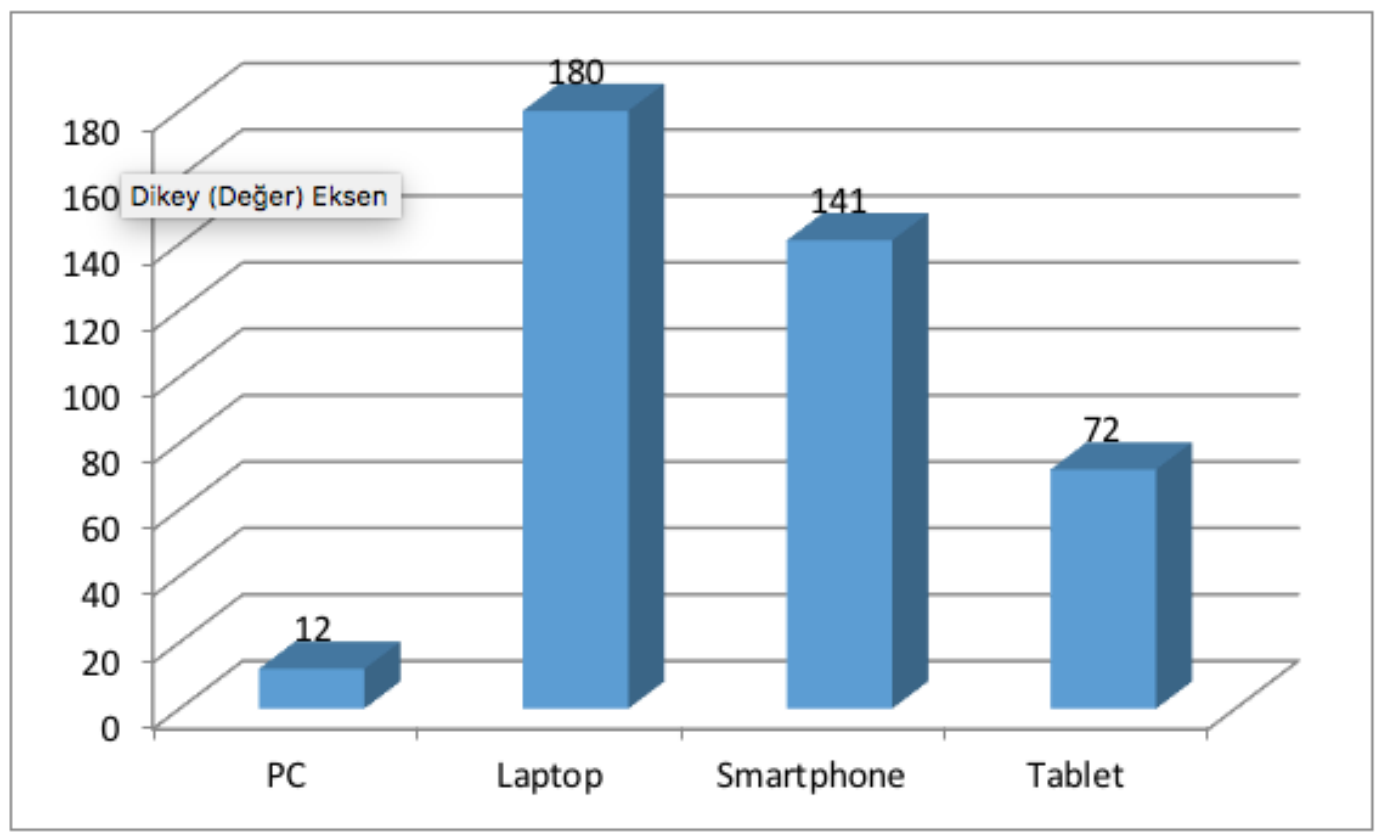

Graph 1. Technological Tools Used

When Graph 1 is examined, it is seen that mathematics teachers use laptop computers mostly, followed by smartphone and tablet respectively. In Graph 2, which aims to use the Internet, it is seen that teachers generally use it for education and e-government, banking, e-commerce, etc. purposes.

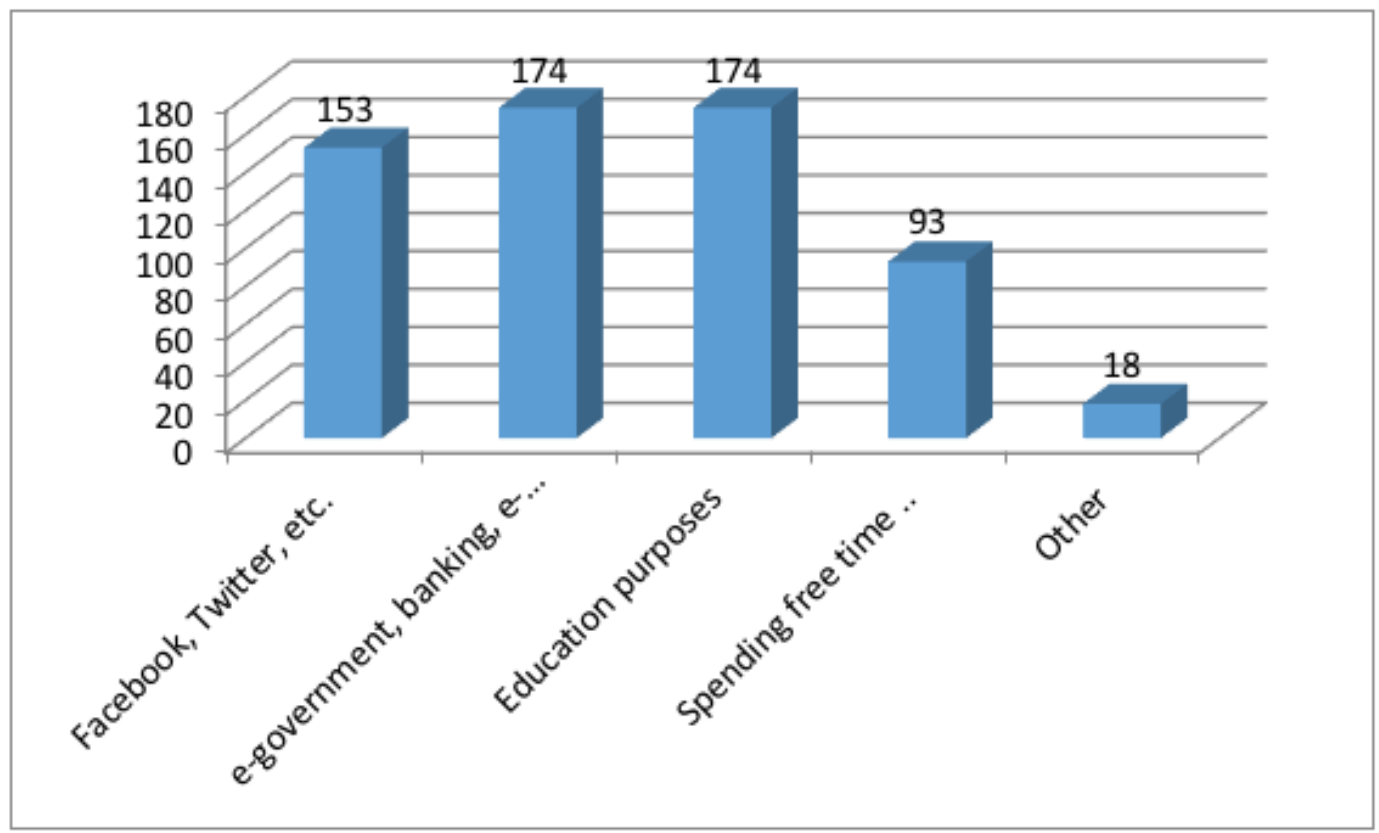

Graph 2. Purpose of Internet Use 


\section{Data Collection Tools and Data Analysis}

In the study, distance education attitude scale and opinion form were used as data collection tools. The data were collected online on the website www.surveey.com between 20 March and 20 June 2020. The Distance Education Attitude Scale developed by Agir, Gur and Okcu (2008) was used to measure the attitudes of mathematics teachers towards distance education. After the pilot study, it was observed that the items were grouped under 6 factors. These factors were reduced to 2 factors: "advantages of distance education" consisting of 14 positive items and "limitations of distance education" consisting of 7 negative items by consulting experts (Agir, Gur and Okcu, 2008). In this study, while calculating the attitude score, it was evaluated as a single dimension and analyzed in line with the suggestions of the researchers. Items of the scale were adapted to apply them to mathematics lessons and teachers and then validity and reliability analyzes were made. The construct validity of the scale was provided by doing exploratory factor analysis. Cronbach Alpha value of the adapted measurement tool was calculated as 0.801 .

Items on the scale are rated 1, 2, 3, 4, 5, from strongly disagree to strongly agree. The lowest score that can be obtained from the scale is 21 , and the highest score is 105 . The score obtained from the scale shows the attitude towards distance education. It can be inferred that the attitude towards distance education is negative as the mean scores decrease. The score range coefficient required for the evaluation of arithmetic averages is determined as 0.80 (Tekin, 1996). The ranges to be used in evaluating the attitude scores of the participants are shown in Table 2. In negative items, reverse scoring was made.

The mean scores of the items in the scale were calculated and shown, $t$ test and Anova (one-way analysis of variance) were applied to determine the differences of the attitudes of mathematicss teachers towards distance education according to demographic variables, and Scheffe test was performed to determine the difference. It was examined whether the study group showed normal distribution, as a result of the analysis the following scores were noted skewness $=-.362$; kurtosis (=. 543). Also, according to the results of Kolmogorov - Smirnov test (.184), it was observed that the attitude scores showed normal distribution. It was decided to apply parametric tests after meeting the basic assumptions.

Table 2. The Levels Used in Commenting Attitude Scores of Teachers towards Distance Education

\begin{tabular}{lcc}
\hline Level & Score & Limits (Mean) \\
\hline Strongly Agree & 5 & $4.20-5.00$ \\
Agree & 4 & $3.40-4.19$ \\
Neutral & 3 & $2.60-3.39$ \\
Disagree & 2 & $1.80-2.59$ \\
Strongly Disagree+++ & 1 & $1.00-1.79$ \\
\hline
\end{tabular}

In the opinion form, three open-ended questions developed to determine the opinions about the mathematics lessons conducted by distance education were asked to the teachers:

1. What are your views on the benefits of distance education in mathematics lessons?

2. What are the limitations and problems encountered in the implementation of distance education in mathematics lessons?

3. Will distance education be effective in increasing academic achievement and attitude towards the course in mathematics lessons?

In this section, which was analyzed in a qualitative dimension, 44 teachers from 189 participants were asked openended questions and their responses were examined with descriptive analysis technique. As it is known, content analysis was used to analyze the data obtained in this study. The purpose of content analysis is to gather similar data within the framework of certain concepts and themes as a result of in-depth analysis of the data and to interpret them in a way that the reader can understand (Cepni, 2018). In this direction, in the study, the opinions of the teachers were tried to be revealed through direct quotations, by sticking to the original form of the data obtained from the teachers.

While applying the interview questions, it was stated that the data would not be used for any other purpose other than research, and the participants were made to feel comfortable and in this way, reliability was tried to be increased. In the research, each of the teachers was first coded as T1, T2, T3 ... to keep the information confidential. The data obtained from the interviews were primarily put into writing. Parts not related to the interview questions have been removed. Each interview question was handled as a category and codes were collected under these categories. For example; For the benefits category of distance education, codes such as continuity and classroom domination were 
determined in line with teachers' opinions. The data were first coded by the first researcher, then the codings were checked by other researchers. For codes where no consensus was reached, a joint decision was made by re-reading the data. The data obtained were repeatedly read by the researchers and a full consensus was attempted while coding. The internal validity of the research was ensured by looking at the significance and consistency of the data. In all processes of the research, expert opinions were asked, they were asked to give feedback with a critical perspective, and the findings obtained in this way were presented under categories.

\section{FINDINGS}

This study focuses on determining attitudes of teachers towards distance mathematics education and examining their views based on some variables. The findings obtained from attitude scale and view forms are presented below.

\section{Findings obtained from Attitude Scale towards Distance Education}

Mean scores of items in attitude scale applied to teachers of mathematics conducting their course via distance education are given below.

Table 3. Items and Mean Scores of Attitude Scale towards Distance Education

\begin{tabular}{|c|c|c|}
\hline No & Items & Mean \\
\hline 1. & Distance education is more effective than traditional education in mathematics lessons. & 1,84 \\
\hline 2. & Learning in distance education is more enjoyable than traditional education in mathematics lessons. & 2,03 \\
\hline 3. & Better results are gained from distance education applications in mathematics lessons.. & 2,37 \\
\hline 4. & Mathematics lessons in distance education should be more commonly used. & 2,46 \\
\hline 5. & Time is used more effectively in mathematics lessons in distance education. & 2,41 \\
\hline 6. & Mathematics lessons in distance education make learning more permanent. & 2,29 \\
\hline 7. & Conducting mathematics lessons in distance education improves self-assessment skills. & 2,67 \\
\hline 8. & $\begin{array}{l}\text { Getting scores of assessment and evaluation immediately in mathematics lessons in distance education } \\
\text { increases motivation of students. }\end{array}$ & 3,08 \\
\hline 9. & Mathematics lessons in distance education provide flexibility of rehearsing as much time as one wants. & 3,63 \\
\hline 10. & $\begin{array}{l}\text { Being not limited to time and place provides sustainability of education in mathematics lessons in distance } \\
\text { education. }\end{array}$ & 3,54 \\
\hline 11. & I like taking mathematics lessons in distance education. & 2,44 \\
\hline 12. & $\begin{array}{l}\text { Mathematics lessons in distance education are more effective in solving problems caused in applications of } \\
\text { traditional education. }\end{array}$ & 2,27 \\
\hline 13. & Everyone can take education fitting to their own level of mathematics lessons in distance education. & 3,10 \\
\hline 14. & $\begin{array}{l}\text { Mathematics lessons in distance education supplies effective learning by means of audio, visual designs } \\
\text { and technology. }\end{array}$ & 3,30 \\
\hline 15. & Tracking success processes of individuals is easier in mathematics lessons in distance education. & 2,84 \\
\hline 16. & Face to face education is needed to give mathematics education in the best way. & 4,22 \\
\hline 17. & Traditional education is more useful than distance education in mathematics lessons. & 3,95 \\
\hline 18. & Mathematics lessons in distance education causes problems in terms of implementation. & 3,83 \\
\hline 19. & $\begin{array}{l}\text { Managing educational environment cannot be done in a healthy way in mathematics lessons in distance } \\
\text { education. }\end{array}$ & 3,92 \\
\hline 20. & Mathematics lessons in distance education cannot be implemented in a healthy way in our country. & 3,32 \\
\hline \multirow[t]{2}{*}{21.} & Student motivation is low in distance education in mathematics lessons as there is no face to face education. & 3,84 \\
\hline & Total & 2,74 \\
\hline
\end{tabular}


Table 3 demonstrates that the highest mean score of the items in attitude scale towards distance education belongs to "Face to face education is needed to give mathematics education in the best way." $(=4,22)$, and the lowest mean score belongs to "Distance education is more effective than traditional education in mathematics lessons." $(=1,84)$.

The mean score of the item 16 was found between 4.20-5.00, and the mean score of the items 9, 10, 17, 18, 19 and 21 was found between 3.40-4.19. This show that teachers strongly agree with item 16 and they agree with other items. When items were examined carefully, it can be seen that teachers strongly agree with the idea that education should be conducted face-to-face to make it in the best way. They also agree with the idea that distance education is useful in terms of rehearsing as many time as one wishes, not being limited with time and place, and sustainability of education. Moreover, it was found that teacher show negative attitude towards distance education as they remarked management of learning environment cannot be done in a healthy way, learning won't be permanent, there would be problems with implementation and student motivation would be low.

The mean score of the items 7, 8, 14, 15 and 20 was found between 2.60-3.3.39. This indicates that teachers are neutral on these items.

According to the findings in table 3, the mean score of the items 1, 2, 3, 4, 5, 6, 11,12 was found between 1.80-2.59. When some of these items were examined in a detailed way, it was found that teachers don't agree with the items "Learning in distance education is more enjoyable than traditional education in mathematics lessons.", "Better results are gained from distance education applications in mathematics lessons.", and "Mathematics lessons in distance education should be more commonly used."

Table 3 reveals that mean attitude scores of mathematics teachers towards distance education are between ( $=54.8,=2.74)$ and their attitudes seem neutral in favor for negative. Moreover, a One-way variance analysis (ANOVA) and independent $\mathrm{t}$-tests were conducted to find out whether attitude scores of mathematics teachers towards distance education differ in terms of variables like age, occupational experience, type of school, level of education and foreknowledge towards distance education, gender and duration of internet use. Findings are presented in Table 4.

Table 4. One-way variance analysis (ANOVA) and independent t-tests analysis results of attitude scores of mathematics teachers towards distance education in terms of various variables

\begin{tabular}{|c|c|c|c|c|}
\hline School Types & $x$ & ss & $\mathrm{F}$ & $\mathrm{p}$ \\
\hline Primary & 2,5423 & ,44951 & \multirow{3}{*}{5,443} & \multirow{3}{*}{, $005^{*}$} \\
\hline Secondary & 2,8404 & ,57834 & & \\
\hline High School & 2,7202 & ,58343 & & \\
\hline Age & & ss & $\mathrm{F}$ & $\mathrm{p}$ \\
\hline Between 20 - 30 & 2,9167 & ,56159 & \multirow{4}{*}{4,149} & \multirow{4}{*}{, $007^{*}$} \\
\hline Between 31 - 40 & 2,7166 & ,54290 & & \\
\hline Between 41 - 50 & 2,5238 & ,53809 & & \\
\hline 51 and over & 2,3333 & ,54028 & & \\
\hline Gender & $x$ & ss & $T$ & $p$ \\
\hline Female & 2,7277 & ,52917 & \multirow[t]{2}{*}{,- 495} & \multirow[t]{2}{*}{ 601 } \\
\hline Male & 2,7731 & 63450 & & \\
\hline Education Level & $x$ & ss & $\mathrm{t}$ & $\mathrm{p}$ \\
\hline Undergraduate & 2,6606 & ,53095 & \multirow[t]{2}{*}{$-6,508$} & \multirow[t]{2}{*}{, $000^{*}$} \\
\hline Graduate & 3,2857 & 42476 & & \\
\hline Experience & $x$ & ss & $\mathrm{F}$ & $\mathrm{p}$ \\
\hline
\end{tabular}




\begin{tabular}{|c|c|c|c|c|}
\hline $1-5$ years & 2,6571 & ,51921 & \multirow{5}{*}{4,311} & \multirow{5}{*}{, $002^{*}$} \\
\hline $6-10$ years & 2,8968 & ,46835 & & \\
\hline $11-15$ years & 2,7242 & ,64022 & & \\
\hline $16-20$ years & 2,5060 & ,43910 & & \\
\hline 21 years and above & 2,1905 & 36515 & & \\
\hline Weekly Usage of Internet & $x$ & ss & $\mathrm{F}$ & $\mathrm{p}$ \\
\hline 1- 2 days & 2,9841 & 60851 & \multirow{4}{*}{2,638} & \multirow{4}{*}{051} \\
\hline 3- 4 days & 2,7857 & ,52616 & & \\
\hline $5-6$ days & 2,8714 & ,46810 & & \\
\hline Everyday & 2,6593 & ,56592 & & \\
\hline Foreknowledge on DE & $x$ & ss & $\mathrm{F}$ & $\mathrm{p}$ \\
\hline Less knowledge on DE & 2,6678 & ,56014 & \multirow{3}{*}{3,245} & \multirow{3}{*}{, $041^{*}$} \\
\hline Sufficient knowledge on DE & 2,8238 & 71282 & & \\
\hline Already lectured in DE & 2,9167 & 31982 & & \\
\hline
\end{tabular}

It was found that attitudes of teachers towards distance mathematics education differ significantly based on school type. Related Scheffe test was conducted and it showed that the related difference is between teachers whose school type is secondary and primary in favor of secondary school [F=5,443, $\mathrm{p}=.005]$. Moreover, the highest mean attitude score is secondary school while the lowest one is primary school.

The attitudes of mathematics teachers towards distance education were found to differ significantly based on age $(p=0,05)$. The result of Scheffe test demonstrated that the difference is between teachers with the age group of 20-30 and 50 and above in favor of 20-30 age group [F=4,149, $\mathrm{p}=.007]$. It was found that the attitudes of mathematicss teachers towards distance education decreases as age level increases.

Table 4 indicates that according to $t$-test attitudes of teachers towards distance mathematics education differ significantly based on level education in favor of those with graduate level [ $\mathrm{t}=--6.508, \mathrm{p}=.000]$.

In order to figure out whether attitudes of mathematics teachers towards distance mathematics education differ significantly based on occupational experience, a one way analysis of variance was conducted $[\mathrm{F}=4,311$, $\mathrm{p}=.002]$. Scheffe test revealed that the difference is between teachers with occupational experience of 6-10 years and 21 years and above in favor of 6-10 experience level.

As a result of the variance analysis to find out whether attitudes of mathematics teachers differ in terms of foreknowledge of distance education, it was found that attitudes differ significantly. Scheffe test indicates that the difference is between teachers with low level of foreknowledge and high level of foreknowledge towards distance education $[\mathrm{F}=3,245, \mathrm{p}=.041]$.

The findings in Table 4 demonstrates that attitudes of mathematics teachers towards distance education does not differ in terms of gender [t=-.495, $\mathrm{p}=.601]$ and weekly use of internet $[\mathrm{F}=2,638, \mathrm{p}=.051]$.

\section{Findings obtained from View Forms}

The codes derived from the first question in view form "What are your views on the benefits of distance education in mathematics lessons?" and some quotations of teachers are presented in the following table. 
Table 5. View towards Benefit of Distance Education of Mathematics Lessons

\begin{tabular}{llc}
\hline Codes & Benefit of Distance Education & $f$ \\
\hline Sustainability & "Providing opportunity to carry out courses in any condition" & 13 \\
Classroom & "I find it useful as it prevents students making noise and distraction of attention." & 4 \\
Management & "Distance education made it better in using visual materials." & 11 \\
Use of Materials & "Students can rehearse as many times as they want regardless of time due to recording & 15 \\
\hline
\end{tabular}

Table 5 indicates that teachers remarked that distance education is useful in terms of sustainability, classroom management, use of material and being able to rehearse. Many of the teachers commented that education could go on since distance education makes it possible to carry out classes in any condition.

The codes derived from the second question in view form "What are the limitations and problems encountered in the implementation of distance education in mathematics lessons?" and some quotations of teachers are presented in Table 6.

Table 6. Views on limitations and problems encountered in the implementation of distance education in mathematics lessons

\begin{tabular}{|c|c|c|}
\hline Codes & Limitations and Problems of Distance Education & $f$ \\
\hline \multirow[t]{2}{*}{ Technical problems } & $\begin{array}{l}\text { “Problems while using live course applications on EBA, except from internet } \\
\text { connection. }\end{array}$ & 21 \\
\hline & "Low speed internet connection, systematic problems" & \\
\hline \multirow[t]{2}{*}{$\begin{array}{l}\text { Teacher Proficiency of } \\
\text { Technology }\end{array}$} & $\begin{array}{l}\text { "Teachers cannot convey concepts of mathematics properly if they are not } \\
\text { competent in use of technology." }\end{array}$ & 7 \\
\hline & $\begin{array}{l}\text { "We were pushed in to the system without getting any training, teachers with no } \\
\text { familiarity of tech-teaching are having great problems" }\end{array}$ & \\
\hline \multirow[t]{3}{*}{ Working Discipline } & "It is problematic since we cannot see how students follow courses." & \\
\hline & $\begin{array}{l}\text { "Not being able to keep track of students like how students follow courses and do } \\
\text { they take notes or not?" }\end{array}$ & 8 \\
\hline & "Eye contact is missing, gestures and mimicry don't contribute to teaching." & \\
\hline \multirow[t]{3}{*}{ Lack of Interaction } & & \\
\hline & $\begin{array}{l}\text { "Lack of interaction during preparations of learning and not being able to } \\
\text { maintain group interaction" }\end{array}$ & \\
\hline & "We cannot make face-to-face interaction with kids during courses" & 14 \\
\hline \multirow[t]{2}{*}{ Learning Environment } & "..., the effect of external sounds to live courses" & \\
\hline & $\begin{array}{l}\text { "It is getting harder to keep a student, who is not interested in mathematics } \\
\text { education, in front of the screen" }\end{array}$ & 6 \\
\hline \multirow{2}{*}{ Structure of the Course } & $\begin{array}{l}\text { "It is really hard to write mathematicsal formulas and terms in most of computer } \\
\text { applications. Drawing graphics, writing solution of problems is also difficult." }\end{array}$ & \\
\hline & $\begin{array}{l}\text { "As mathematics is already a course which people have predijuce, I don't think it } \\
\text { can be understood well enough via distance education." }\end{array}$ & 17 \\
\hline
\end{tabular}


In Table 6, teachers remarked that mathematics education in distance education has some limitations and problems like technical problems, teacher skills, working discipline, and limitations in interaction, learning environment and structure of courses. Within these expressions technical problems and not being compatible with structure of the course have been commented by many of the teachers.

The codes derived from the third question in view form "Will distance education be effective in increasing academic achievement and attitude towards the course in mathematics lessons?" and some quotations of teachers are presented in Table 7.

Table 7. Views on The effect of Distance Education on Academic Success and Attitude

\begin{tabular}{ll}
\hline Codes & The Effect of Distance Education on Academic Success and Attitude \\
\hline Positive & "It will definitely be effective. Students who motivate themselves at school would also \\
become successful in distance education." & "It will certainly be effective in motivation, activity and, testing and evaluation parts of the \\
& course. Using educational technologies while giving courses facilitates reaching course \\
& objectives and gains faster." \\
& "I don't think distance education increases academic achievement in mathematics \\
& lessons. It might help partially but generally speaking it is more limited compared to \\
& verbal courses." \\
& "It increases if it is used additional to regular education but distance education solely \\
& can't be effective in increasing academic success." \\
"It might increase attitude to course if distance education supplements active learning \\
period. It might increase academic success as teachers have data which they can use in \\
the analysis of the parts they find difficult to deal with." \\
"No. As mathematics is a lesson based on practice, I think traditional education is the most \\
effective method in increasing academic success and attitude." \\
"No, it cannot be. Mathematics should be given in one-to-one mode. Adaptation to the \\
lesson is already a problem, It is a biased subject." \\
"To me, union of place and face-to-face education is a must for academic success in \\
mathematics."
\end{tabular}

Table 7 reveals that 10 of teachers commented positively, 15 of them commented partially positive and 19 of them commented negatively on mathematics lessons in distance education towards increasing academic success and attitude.

\section{DISCUSSIONS AND CONCLUSION}

The results of the study indicating views and attitudes of teachers towards mathematics lessons in distance education during Covid 19 pandemic were presented and discussed along with the addressed research questions. Firstly, attitudes of teachers towards courses conducted via distance education were taken into consideration. When findings obtained from attitude scale were examined wholly, they are in a neutral level. Ates and Altun (2008) also claimed that attitudes of teachers are neutral. On the contrary many there have been many studies indicating positive attitudes of teachers towards distance education and they are willing to attend distance learning activities (Agir, Gur and Okcu, 2008; Celen, Celik and Seferoglu, 2013; Yenilmez, Balbag and Turgut, 2017). It might be thought that these differences in view of teachers towards distance education might stem from course contents and the way the courses are given.

When the findings obtained from attitude scale of distance education were examined, it was understood that most of teachers agree on the items of "being not limited to time and place", and "being able to listen to the courses anytime", "being able to rehearse the topics they mostly have trouble with". According to findings of view form, they also remarked that distance education mathematics lessons have some benefits like sustainability, classroom management, use of materials and rehearsing chances. Even teachers who don't 
use any materials in conventional education expressed that distance education presents alternative learning methods with visual and digital materials and these might be helpful in subjects like geometry. These findings support the results of attitude scale. There have been a number of studies in the literature stressing out that some features including being independent from time and place, and giving more opportunities for rehearsing are the most positive features of distance education (Aggarwal, 1999; Belcheir and Cucek, 2002; Sharples, Taylor and Vavoula, 2005; Eygu and Karaman, 2013; Ozgol, Sarikaya and Ozturk, 2017).

One of the results derived from the scale and the view form is that both teachers and learners have some sort of concerns like not getting motivated and low level of motivation due to lack of face to face interaction. A great deal of studied documented that low interaction between teacher-learner, learner-teacher due to lack of interaction causes major problems in distance education (Galusha, 1997; Wood, 1998, Yazici, Altas and Demiray, 2001; Usun, 2006; Falowo, 2007; Li, 2009; Tryon and Bishop, 2009; Isman, 2011).

Birisci (2013) argues that learners being educated with distance education have been facing lack of motivation in distance education activities. As there is no teacher-learner interaction in asynchronous courses where there is no face to face communication, reactions, mimicries or body language movements are not seen. Not being able to ask questions face to face is another limitation. Mathematics lessons have a conceptual structure and these concepts can also be taught in face to face fashion. Thus this prevents these courses to be conducted effectively.

Most of the teachers participating in the research stated that they have sufficient knowledge about distance education or have taught about distance education before. In addition, it has been observed that they use the internet frequently and generally for educational purposes, and they have the necessary technological tools personally. Teachers' limited competencies and skills to provide distance education, and significant differences between their competencies in terms of using and accessing digital tools may cause difficulties in carrying out this process effectively. Teachers who can reach all students through communication channels and have sufficient technological skills may be insufficient for some courses, grade levels, age groups and students in distance education. The teachers stated that primary school students in terms of grade level and age group felt deficient in distance education in lessons that include applications such as mathematics and science.

Teachers commented in view form that technological problems affect distance education process; therefore distance education can't improve academic success and attitude towards mathematics lesson. There have been many studies in the literature stress out technical problems like internet connection and power cut (Bonk, 2001; Goktas and Kayri, 2005; Turkey Informatics Council, 2002; Koppelman and Vranken, 2008; Marsh, Mitchell and Adamczyk, 2010; Isman, 2011; Koparan and Yilmaz, 2020). Koc (2017), on the other hand, student success in distance education should be fostered by increasing attendance via appealing learning activities and discussion forums. There have been many studies indicating that distance education is effective in increasing student success (Hwang and Chang, 2011; Martin and Ertzberger, 2013; Song, 2014; Yorganci, 2014; Koparan and Yilmaz, 2020). Thus, teachers should be guided by examining and having an opinion on the methods used in activities which increases student success.

Another research problem of the study is to examine attitude of mathematics teachers towards distance education in terms of variables like age, occupational experience, type of school, level of education and foreknowledge towards distance education, gender and duration of internet use. Findings indicate that attitude of teachers towards distance education did not significantly differ based on variables of gender and duration of internet use. This is in line with the findings of Agir et al. (2008). Ates and Altun (2008), Yenilmez and et al (2017) stated that gender has an effect on attitude. Once again Yenilmez and et al (2017) concluded that duration of internet use has no effect on attitudes of teachers towards distance education. Thus, it might be inferred that gender is not a determinant factor on attitudes.

Significant differences were found between attitudes of teachers towards distance education and age, occupational experience, type of school, level of education and foreknowledge towards distance education. In terms of age variable, it can be said that 20-30 age group has a more positive attitude and mean attitude score decreases as age level increases. Tucker (2011) claims that there is no significant difference between attitudes towards education and age. From the perspective of occupational experience, teachers with 6-10 years of experience have more positive attitudes towards distance education. This finding is coherent with age variable. There have been many studies in the literature claiming that there are significant differences based on occupational experience in belief and attitude studies towards distance education. Findings derived from studies in the literature support the findings of this study. 
In terms of school type, the difference was found between teachers in secondary school and primary school. Agir, Gur and Okcu (2008), in their study examining attitudes of primary school teachers, found that attitudes of teachers did not significantly differ in terms of schools they work.

As for level of education, attitudes of teachers toward distance education seem to differ significantly in favor of teacher with graduate degrees. Moreover, based on the variable of foreknowledge towards distance education significant differences were found between teachers who have given distance education before and those who have low and sufficient level of foreknowledge towards distance education. Studies have given support that having foreknowledge towards distance education affects attitudes towards distance education (Agir, Gur and Okcu, 2008; Ates and Altun, 2008; Yenilmez, Balbag and Turgut, 2017). This is in line with the findings of this study.

In conclusion, it is understood that attitudes and views of teachers towards mathematics lessons which have been conducted via distance education are inconclusive and indecisive. Teachers who don't want to be a part of distance education might decrease motivations of teachers and learners who have adopted and possibly adopt this structure with their negative comments during this distance education period where it is no longer an alternative but mandatory. Preparations should be done before distance education process and views, wishes and suggestions of teachers should be kept in mind before taking action. Problems of content, use of material and assessment and evaluation methods should be fixed. Assessment and evaluation, even though it was not used effectively in this process, is a major problem in distance education. Distance education and following exams conducted in our universities show it clearly how we lack in assessment and evaluation. However, considering that the distance education process implemented in this process is not a planned activity and is an urgent and mandatory process, these deficiencies are expected.

There have been many problems related with the use of distance education in mathematics education. Although the process is pretty new, results of this study demonstrates that experimental studies focusing on how distance education methods can be used in a more dynamic way should be conducted and the number of these studies should be increased to contribute to solution of the problem. Parallelly, the process might be supported with implementations in diverse levels and courses by taking into account of both teachers' and learners' needs and wishes. Moreover, attitude scale of distance education unique to mathematics lesson might be developed with inclusion of assessment and evaluation experts to the study. It is important to establish a solid infrastructure for distance education support services in our schools and to provide continuous support to students. In addition, quantitative and qualitative studies can be carried out by taking the opinions of teachers, students, and distance education process managers in order to provide in-service training to educators on distance education and to evaluate emergency distance education in education systems during the pandemic period.

\section{BIODATA and CONTACT ADDRESSES of AUTHORS}

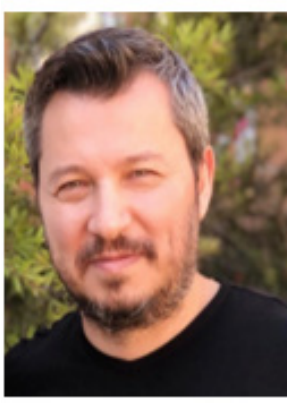

Baris DEMIR is lecturer at Kocaeli University Hereke Omer Ismet Uzunyol Vocational School and Ph.D. student at Bursa Uludag University Mathematics Education. His academic interests are mathematics education and mathematical modeling. He has articles and presentations on these topics.

\section{Baris DEMIR}

Hereke Omer Ismet Uzunyol Vocational School

Address: Kocaeli University, Kocaeli, TURKEY

Phone: +902625115675

E-mail: barisprof@yahoo.com 


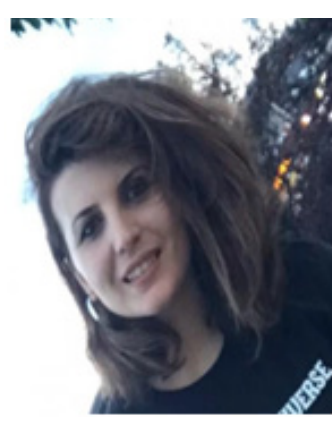

Dr. Gul KALELI-YILMAZ works as an associate professor at Bursa Uludag University. She received her undergraduate and graduate degrees (PhD in 2012) in the field of mathematics teaching from Karadeniz Technical University. Her research is mainly on technological pedagogical content knowledge, mathematics and geometry education. She has journal articles published in international and national indexes, book chapters and papers presented to international meetings.

Gul KALELI-YILMAZ

Bursa Uludag University Faculty of Education Department of Mathematics and Science Education Address: Bursa Uludag University, Bursa, TURKEY

Phone: +90 02242942157

E-mail: gulkaleli@uludag.edu.tr

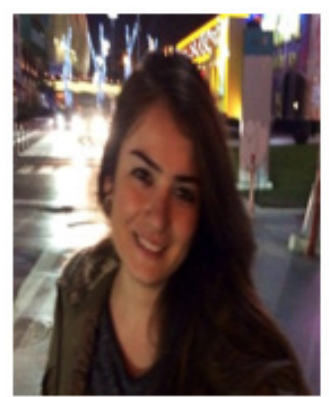

Hulya SERT- CELIK is a mathematics teacher at a secondary school affiliated to national education and a doctoral student at Bursa Uludag University. Her academic interests are mathematics and geometry education. She has articles and presentations on these topics.

Hulya SERT- CELIK

Icmeler I.C.K.K.A Secondary School

Address: Mugla, TURKEY

Phone: +90 2524553045

E-mail: hlyasert@gmail.com

\section{REFERENCES}

Aggarwal, A. K. (Ed.). (1999). Web-Based Learning and Teaching Technologies: Opportunities and Challenges, IGI Global.

Agir, F. (2007). Ozel Okullarda ve Devlet Okullarinda Calisan Ilkogretim Ogretmenlerinin Uzaktan Egitime Karsi Tutumlarinin Belirlenmesi [Determinig the Teachers' Attitudes Towards Distance Education In Public Primary School And Private Primary School] (Master's dissertation) Balikesir University Graduate School of Science Sciences, Balikesir, Turkey.Balikesir. Available from the Council of Higher Education, National Dissertation Center, Dissertation ID: 177901.

Agir, F., Gur, H. \& Okcu, A. (2008). Uzaktan egitime karsi tutum olcegi gelistirilmesine yonelik gecerlik ve guvenirlik calismasi [Development Of The Attitude Scale Toward Distance Learning: Reliability And Validity]. e-Journal of New World Sciences Academy, 3(2), 128-139.

Alakoc, Z. (2001). Genel olarak uzaktan ogretim ve konuya ogretim uyelerinin bakis acilari. [Distance education in general and faculty's perspectives on the subject] Sakarya Universitesi Egitim Fakultesi Dergisi, 3, 403-413.

Ates, A., \& Altun, E. (2008). Bilgisayar oğretmeni adaylarinin uzaktan eğitime yonelik tutumlarinin cesitli degiskenler acisindan incelenmesi [Investigating Preservice Computer Teachers' Attitudes Towards Distance Learning Regarding Various Variables]. Gazi Universitesi Egitim Fakultesi Dergisi, 28(3), $125-145$. 
Baek, Y., Zhang, H. \& Yun, S. (2017). Teachers' attitudes toward mobile learning in Korea. The Turkish Online Journal of Educational Technology, 16 (1), 154- 163.

Bahcesehir University Report,(2020), Retrieved April 20, 2020 from https://www.cumhuriyet.com.tr/ haber/uzaktan-egitim-raporu-aciklandi-uzaktan-olmuyor 1739116.

Belcheir, M. J. \& Cucek, M. (2002). Faculty Perceptions of Teaching Distance Education Courses. Research Report 2002. (ERIC Document Reproduction Service No: ED 480 925).

Birisci, S. (2013). Video konferans tabanli uzaktan egitime iliskin ogrenci tutumlari ve gorusleri. [Attitudes and Opinions of Students on Video Conference Based Distance Education] Journal of Instructional Technologies \& Teacher Education, 1(2), 24-40.

Bonk, C. (2001). Online teaching in an online world. http://www.publicationshare.com/docs/faculty_ survey_report.pdf.

Creswell, J. W. (2003). Research design: Qualitative, quantitative, and mixed methods approaches (2nd ed.). Thousand Oaks, CA: Sage.

Creswell, J., \& Plano Clark, V. L. (2007). Understanding mixed methods research. In J. Creswell (Ed.), Designing and conducting mixed methods research (pp. 1-19). Thousand Oaks, CA: Sage.

Celen, F.K., Celik, A., \& Seferoğlu, S.S. (2013). Analysis of teachers' approaches to distance education. Procedia-Social and Behavioral Sciences, 83, 388-392.

Cepni, S. (2018). Arastirma ve proje calismalarina giris. (8.Baski).[ Introduction to research and project studies. (8th Edt.)] Trabzon: Celepler Matbaacilik.

Cetin, O. (2010). Fen ve Teknoloji Dersinde "Coklu Ortam Tasarim Modeli”ne Gore Hazirlanmis Web Tabanli Ogretim Iceriginin Ogrenci Basari ve Tutumlarina Etkisi ile Icerige Yonelik Ogretmen ve Ogrenci Goruslerinin Degerlendirilmesi [The Assessment of the Effects of Web-Based Teaching which is Designed According to "Hypermedia Design Model" in Science and Technology Classes to the Academic Performance and Attitudes of Students and the Assessment of the Views of Teachers and Students about the Content of Web-Based Teaching](Doctoral dissertation). Dokuz Eylul University Graduate School of Educational Sciences, Izmir, Turkey. Available from the Council of Higher Education, National Dissertation Center, Dissertation ID: 265514.

Cetinkaya Aydin, G. 2020. "COVID-19 Salgini Surecinde Ogretmenler”. Tedmem., Retrieved May 17, 2020 from https://tedmem.org/covid-19/covid-19-salgini-surecinde-ogretmenler.

Delaney, G., Jacob, S., Iedema, R., Winters, M., \& Barton, M. (2004). Comparison of faceto-face and videoconferenced multidisciplinary clinical meetings. Australasian Radiology, 48(4), 487-492.

Durak, G., Cankaya, S. \& Izmirli, S. (2020). COVID-19 Pandemi Doneminde Turkiye'deki Universitelerin Uzaktan Egitim Sistemlerinin Incelenmesi [ Examining the Turkish Universities' Distance Education Systems During the COVID-19 Pandemic]. Necatibey Faculty of Education, Electronic Journal of Science and Mathematics Education, 14(1), 787-809.

Eygu, H., \& Karaman, S. (2013). Uzaktan Egitim Ogrencilerinin Memnuniyet Algilari Uzerine Bir Arastirma [A Study on the Satisfaction Perceptions of Distance Education Students]. Kirikkale Universitesi Sosyal Bilimler Dergisi, 3(1), 36-59.

Falowo, R. O. (2007). Factors impeding implementation of web-based distance learning. AACE Journal, 15(3), 315-338.

Galusha, J. M. (1997). Barriers to learning in distance education. Interpersonel Computing and Technology: An Electronic Journal of the 21st Century, 5(3-4), 6-14.

Gokcek, T. (2019). Karma Arastirma Yontemi [Mixed Research Method]. In H. Ozmen \& Orhan Karamustafaoglu (Ed.), Research Methods in Education (pp. 388-435). Ankara: Pegem Akademi.

Gokdas, I., \& Kayri, M. (2005). E-ogrenme ve Turkiye acisindan sorunlar, cozum onerileri [E-Learning and Turkey in terms of problems, solution]. Yuzuncu Yil Universitesi Egitim Fakultesi Dergisi, 2(2). 
Greene, J.C., Caracelli, V.J., \& Graham, W.F. (1989). Toward a conceptual framework for mixed- method evaluation designs. Educational Evaluation and Policy Analysis, 11(3), 255-274.

Horzum, B. (2003). Ogretim elemanlarinin internet destekli egitime yonelik dusunceleri (Sakarya universitesi ornegi).Yuksek lisans tezi. Sakarya Universitesi Sosyal Bilimler Enstitusu, Sakarya. [Ideas of lectures about internet based education (Sakarya University Examples)] (Master's dissertation) Sakarya University Graduate School of Social Sciences, Sakarya, Turkey.Sakarya. Available from the Council of Higher Education, National Dissertation Center, Dissertation ID: 136842.

Horzum, M. B., Albayrak, E. \& Ayvaz, A. (2012). Sinif Ogretmenlerinin Hizmet Ici Egitimde Uzaktan Egitime Yonelik Inanclari. [Elementary Classroom Teachers' Beliefs on In-Service Training via Distance Education]. Ege Egitim Dergisi 13(1), 56-72.

Hwang, G.J. \& Chang, H.F. (2011). A formative assessment-based mobile learning approach to improving the learning attitudes and achievements of students. Computers \& Education, 56(4), 1023-1031.

Isman, A. (2005). Uzaktan Egitim [Distance education]. Ankara: Ogreti Press.

Isman, A. (2011). Uzaktan Egitim [Distance education]. Ankara: Pegem Akademi Press.

Javed, S. H. (2008). Online facilitated mathematicss learning in vocational education: A design-based study. Unpublished doctoral dissertation. Victoria Universitesi.

Karip, E. 2020. "COVID-19: Okullarin Kapatilmasi ve Sonrasi”, em. Retrieved May 1, 2020 from https:// tedmem.org/vurus/covid-19-okullarin-kapatilmasi-ve-sonrasi.

Kaleli-Yilmaz, G. \& Guven, B. (2015). Ogretmen Adaylarinin Uzaktan Egitime Yonelik Algilarinin Metaforlar Yoluyla Belirlenmesi [ Determining the Teacher Candidates' Perceptions on Distance Education by Metaphors] Turk Bilgisayar ve Matematik Egitimi Dergisi, 6(2), 299-322.

Koc, M. (2017). Learning analytics of student participation and achievement in online distance education: A structural equation modeling. Educational Sciences: Theory \& Practice, 17, 1893-1910.

Koparan, T. \& Yilmaz, G.K. (2020). Matematik Ogretmeni Adaylarinin Mobil Ogrenme Ile Desteklenen Ogrenme Ortamina Yonelik Gorusleri [Opinions of Pre-Service Mathematicss Teachers' on the Learning Environment Supported by Mobile Learning]. Uludag Universitesi Egitim Fakultesi Dergisi, 33(1), 109-128.

Koppelman, H., \& Vranken, H. (2008). Experiences with a synchronous virtual classroom in distance education. ITICSE'08 Madrid, 194-198.

Li, X. (2009). Review of distance education used in higher education in China. Asian Journal of Distance Education, 7(2), 22-27

Li, K., Uvah, J., Amin, R., \& Hemasinha, R. (2009). A study of non-traditional instruction on qualitative reasoning and problem solving in general studies mathematicss courses. Journal of Mathematicsal Sciences and Mathematicsal Education, 4(1), 37-49.

Lin, C. (2009). A comparison study of web-based and traditional instruction on preservice teachers' knowledge of fractions. Contemporary Issues in Technology and Teacher Education, 9(3), 257-279.

Marsh, B., Mitchell, N., \& Adamczyk, P. (2010). Interactive video technology: Enhancing Professional learning in initial teacher education. Computer \& Education, 54(3), 742- 748.

Martin, F., \& Ertzberger, J. (2013). Here and now mobile learning: An experimental study on the use of mobile technology. Computers \& Education, 68, 76-85.

Ozgol, M., Sarikaya, I., \& Ozurk, M. (2017). Orgun egitimde uzaktan egitim uygulamalarina iliskin ogrenci ve ogretim elemani degerlendirmeleri. [ Students' and Teaching Staff's Assessments Regarding Distance Education Applications in Formal Education]. Journal of Higher Education and Science, 7(2), 294-304.

Ozyurt, H. (2012). Implementation and evaluation of a web based mathematicss teaching system enriched with interactive animations for the probability unit. Energy Education Science and Technology Part B-Social and Educational Studies, 4(3), 1167-1180. 
Paden, R. R. (2006). A comparison of student achievement and retention in an introductory math course delivered in online, face-to-face, and blended modalities. Unpublished doctoral dissertation. Capella University.

S. Wood, (1998). On-line Supported Subjects: A Practical Handbook for Academics, CELT, Charles Sturt University,

Sharples, M., Taylor, J., \& Vavoula, G. (2005). Towards a theory of mobile learning. In Proceedings of m-learn Conference. Cape Town, South Africa.

Song, Y. (2014). Bring your own device (BYOD) for seamless science inquiry in a primary school. Computers \& Education, 74, 50-60.

Surasi, B., \& Basbakanlik, T. (2002). Bilgi Toplumuna Dogru. ODTU Kultur ve Kongre Merkezi, Sonuc Raporu, Ankara.

Tekin, H. (1996). Egitimde Olcme ve Degerlendirme. [ Measurement and Evaluation in Education.]. (9th Edition), Ankara: Yargi Press.

Tryon, P. J. \& Bishop, M. (2009). Theoretical foundations for enhancing social connectedness in online learning environments. Distance Education, 30(3), 291-315.

Tsuei, M. (2012). Using synchronous peer tutoring system to promote elementary students' learning in mathematicss. Computers \& Education, 58, 1171-1182.

Tucker, S. (2001). Distance Education: Better, Worse, or As Good As Traditional Education? Online Journal of Distance Learning Administration, 4(4).

UNESCO. (2020). COVID-19 educational disruption and response. Retrieved April 17, 2020 from https:// en.unesco.org/covid19/educationresponse

Usun, S. (2006). Uzaktan Egitim [Distance education]. Ankara: Nobel Yayin Dagitim.

Yazici, A., Altas, I., \& Demiray, U. (2001). Distance education on the Net: A model for developing countries. Turkish Online Journal of Distance Education-TOJDE, 2(2), 24- 35.

Yenilmez, K., Turgut, M., \& Balbag, M. Z. (2017). Ogretmen Adaylarinin Uzaktan Egitime Yonelik Tutumlarinin Bazi Degiskenler Acisindan Incelenmesi. [ Investigation of Prospective Teachers' Perceptions on Distance Education with Respect to Certain Variables]. Erzincan Universitesi Egitim Fakultesi Dergisi, 19(2), 91-107.

Yorganci, S. (2014). Web Tabanli Uzaktan Egitim Yonteminin Ogrencilerin Matematik Basarilarina Etkileri [The Effects of Web Based Distance Education Method on Students' Mathematicss Achievements]. K. U. Kastamonu Egitim Dergisi, 23 (3), 1401-1420.

Yorganci, S. (2013). The effects of web-based distance mathematicss instruction on mathematicss attitudes and achievements: The case of Erzurum Vocational School. Ejoir, 1, 64-83. 